\title{
E-marketing in MSMEs Managed by Elderly Adults and Young Adults in Aguascalientes, Mexico
}

\author{
Juan R. Gutierrez-Velasco ${ }^{1}$, David Cabral-Olmos ${ }^{2} \&$ Jose T. Marin-Aguilar $^{3}$ \\ ${ }^{1}$ MBA. Professor at Autonomous University of Aguascalientes, Avenida Universidad \# 940, C.U., Zip code: \\ 20131 Aguascalientes, Ags. México \\ ${ }^{2} \mathrm{PhD}$ in Administrative Science, Avenida Universidad \# 940, C.U., Zip code: 20131 Aguascalientes, Ags. \\ México \\ ${ }^{3} \mathrm{PhD}$ in Marketing. Full time Professor at Autonomous University of Aguascalientes, Avenida Universidad \# 940, \\ C.U., Zip code: 20131 Aguascalientes, Ags. México.
}

Correspondence: José T. Marín-Aguilar, Marketing Department, School of Business, Autonomous University of Aguascalientes, Aguascalientes, Mexico.

Received: May 28, 2021

doi:10.5539/ibr.v14n8p100
Accepted: June 23, 2021

Online Published: July 29, 2021

URL: https://doi.org/10.5539/ibr.v14n8p100

\begin{abstract}
The city of Aguascalientes, characterized by having been a pillar in the textile industry in Mexico, has proven to have entrepreneurs who have managed to survive in the face of changes in the economy that redirected productive activities towards industrial manufacturing. The research problem consists of the little knowledge that entrepreneurs have of the digital tools to implement in their businesses and their effects. Thus, the objective of this work is to contrast the impact of the use of e-marketing on business success, according to the age of the people who manage companies in this sector. This research was carried out by means of structural equations, in order to determine the relationship of each of the constructs in the proposed model applied to this group of companies. The results achieved show that E-marketing has a positive and significant influence on business performance; Furthermore, this variable has a greater influence on the micro-enterprises of the textile sector of Aguascalientes managed by young adults.
\end{abstract}

Keywords: e-marketing, business performance, textile and clothing industry, elderly adults, young adults

\section{Introduction}

The accelerated growth that e-commerce has had, added to the lack of knowledge of these tools by micro, small and medium-sized enterprises (MSMEs) and the age of the people who run them, translate into an area of opportunity in the fields of research and commerce. Nowadays, the survival of MSMEs is a popular objective in all economies, so developing strategies focused on competitiveness and performance is of great importance (Valdez, Ramos, \& Borboa, 2019).

In terms of the textile sector worldwide, it was valued at 900 trillion dollars, with a growth rate of $4.3 \%$ by 2020 , being Mexico one of the four most important countries within this industry, only behind China, India, and Bangladesh (Grand view research, 2020). In the case of the Mexican economy, according to data from the National Institute of Statistic and Geography (2020a) - known as INEGI - the textile and clothing industry contributes $3.2 \%$ of the country's gross domestic product (GDP) and gives employment to more than 600, 000 people, without contemplating informal trade.

However, the outlook is not easy in the sector, there are notable problems related to capital, the lack of modernization and innovation, poorly qualified personnel, and bad administrative practices (Villagómez, Montoya \& Figueroa, 2019). In the case of the state of Aguascalientes, although it stood out in the decades of the 60s, 70s and 80s because of the crises and economic opening and, therefore, external competition, there is weakness in the competitive and creative structure of the sector provoking a decline (García, Lozano \& Castorena, 2018).

When it comes to modernization, brands are gradually shifting towards digital platforms as their primary means of communication (The CMO Survey, 2020). E-marketing strategies are changing the world of marketing, and it is believed that it now parallels or even surpasses some traditional marketing strategies Liu, Perry, and Gadzinski 
(2019). The growth of e-marketing is proportional to the number of users who implement measures in this area and the digital tools available; to such a degree that today it represents the method to carry out negotiations at a global level (Selman, 2017).

This research seeks to deepen the study of the use of e-marketing and its impact on the success of MSMEs, having as its main objective to compare the influence it has on the performance of companies in the textile sector managed by young adults against that of companies managed by elderly adults. The methodological approach used in the present research was quantitative and the research method was descriptive correlational.

The structure of the rest of this research obeys the following order: in the next section the theoretical framework is presented; subsequently, section 3 describes the methodology used; section 4 presents the results found and, finally, section 5 shares the main conclusions, contributions, and future lines of study.

\section{Theoretical Framework}

The existence of a competitive advantage in any organization means that it has reached a level of performance superior to that of its competitors, a situation that allows it to obtain better results. Therefore, building and sustaining a competitive advantage represents the key to the success of companies and shows the efficiency in the use of resources and capacities (Fong Reynoso, Flores Valenzuela \& Cardoza Campos, 2017).

Starting in the eighties, explanations regarding business success focus on the study of external factors of the company, in particular the structure of the industry, through Structural Theory (Porter, 1980) and that of internal factors through the Theory of Resources and Capacities (Wernerfelt, 1984; Barney, 1991). There is a growing trend in the RBT due to various factors, among which the accumulation of empirical evidence reported in the international literature can be noted, which indicates that internal factors of the company explain business results to a greater extent than external factors (Fong Reynoso et al., 2017).

The Theory of Resources and Capacities explains that business success is determined by the characteristics of the resources and capacities that the company controls, and the capacity they have to generate income; it also emphasizes the fact that an efficient combination of its resources and capacities allows obtaining and maintaining its competitive advantages (Teece, Pisano \& Shuen, 1997).

For authors such as Kotler and Armstrong (2009), E-MKT refers to the strategies and actions to establish a relationship with users and promote the purchase of products or services, through digital media and tools to establish a positive and lasting relationship. Some authors provide a simpler definition of this, Sosa and Useche (2017), for example, define E-MKT as a form of marketing that uses technological means to project the image of a brand, through advertising on different internet channels. Organizations can generate competitive advantages over other organizations by offering added value to their products or services through digital alternatives (Sosa \& Useche, 2017). In this context, E.-Marketing (EMKT) represents an important tool for organizations because through it they can create, communicate, deliver and exchange offers with value for clients, partners, and the community in general (Bala \& Verma, 2018).

Regardless of complex or simple definitions, E-MKT has to do with the use of information technology and the internet to carry out marketing processes such as defining needs and demands (Khan \& Islam, 2017), creating, communicating, delivering and exchange offers with value for clients, partners and the community in general (Bala \& Verma, 2018) which translates into a competitive advantage over other organizations, offering added value to their products or services through digital alternatives (Sosa \& Useche, 2017). In this context, we can affirm that the E-MKT has surpassed the traditional one, since it increased efficiency and effectiveness, and transformed traditional marketing strategies (Bala \& Verma, 2018).

In line with the above, Mzee, Ogweno and Irene, (2015) reveal in their study that organizations that use the E-MKT in their businesses found that it is not an expense, but an investment that helps them communicate with their customers locally and globally, and although its uses differ from company to company, there is wide acceptance in business settings (Abu Bakar \& Ahmed, 2015). Thus, E-MKT through emails, social media websites, mobile devices and other similar platforms play a fundamental role in capturing customer attention, facilitating the buying / selling process, and sharing information (Stankov, Filimonau \& Slivar, 2019; Usman, Ahmad \& Burgoyne, 2019) which, in turn, helps companies to achieve better performance (Anser, Yousaf, Usman \& Yousaf, 2020).

In addition to the interactive advantages of connecting with consumers (Kotler \& Armstrong, 2009), the E-MKT offers a precise targeting of potential customers (Pandey \& Gudipudi, 2019), which represents a great help for companies trying to optimize their productivity and sales. Likewise, it also helps to track consumer participation and sales conversions in real time and to create dynamic content according to the viewing habits of a potential 
client, all the above improving the performance of companies or organizations (Pandey, Nayal \& Rathore, 2020).

In this setting, we find in Vieira, Almeida, Agnihotri and Arunachalam (2019) different studies that relate E-MKT with business success in the Business to customers (B2C) environment and that focus on brand building and the consumer journey, which implies purchasing and post-purchase activities in the context of developed economies, (Stephen \& Galak, 2012; Li \& Kannan, 2014; Dinner, Heerde \& Neslin, 2014; Maldonado, Garza, Pinzon \& Kumar, 2017; Colicev, Malshe, Pauwels \& Oconnor, 2018), in addition to some with a focus on emerging economies (Maldonado et al., 2017). However, although E-MKT was initially believed to help organizations or commerce activities of B2C companies, the success stories of E-MKT in business-to-business (B2B) companies have gradually changed this (Venkatesh, Mathew \& Singhal, 2019).

The literature on E-MKT in B2B companies had had a greater focus on lead segmentation and subscriber engagement within developed economies (Bruce, Foutz \& Kolsarici 2012; Pandey, et. al., 2020). However, there are studies that show that E-MKT has a positive impact on the performance of B2B companies through customer orientation and optimization of sales productivity (Pandey \& Gudipudi, 2019) or the facilitation of the buying / selling process. and the exchange of information through emails, websites, social networks, mobile devices, and other platforms, resulting into a better performance that eventually translates into the achievement of objectives (Ollo-López \& Aramendía-Muneta, 2012; Stankov, et al., 2019; Usman, et al., 2019).

In the context of business performance, it is said to be measured by indicators previously defined by organizations such as financial resources, production costs, productivity, customer satisfaction, market share, indebtedness, profitability and, above all, the job performance of each member of the organization (Ghermandi, 2018). In addition, we should consider what was presented in Vivanco and Franco (2012), who mention that markets are results-oriented and do not allow errors, therefore, companies must overcome competition and any other situation using all their tools.

From business performance perspective, the textile and clothing industry, according to data from INEGI (2020a) contributed with 3.2\% of the GDP of Mexico's manufacturing industries and was ranked 10th among the most important industries in 2019. The main activities of this industry, considered manufacturing, consists of the transformation of raw materials into different articles for consumption, such as the manufacture of yarns and fabrics, finishing and coating of textiles, manufacturing of carpets, rugs, curtains, clothing, etc. (INEGI 2020b).

The textile sector in Mexico had enjoyed prosperous years following the signing of the North American Free Trade Agreement (NAFTA) in 1994. However, in recent years the performance of this sector has been diminished as can be seen in its contribution to the GDP that has decreased over the years (Ortiz, Gómez \& Rodríguez, 2018). Figure 1 shows the contributions to Mexican GDP of the textile and clothing industry in recent years.

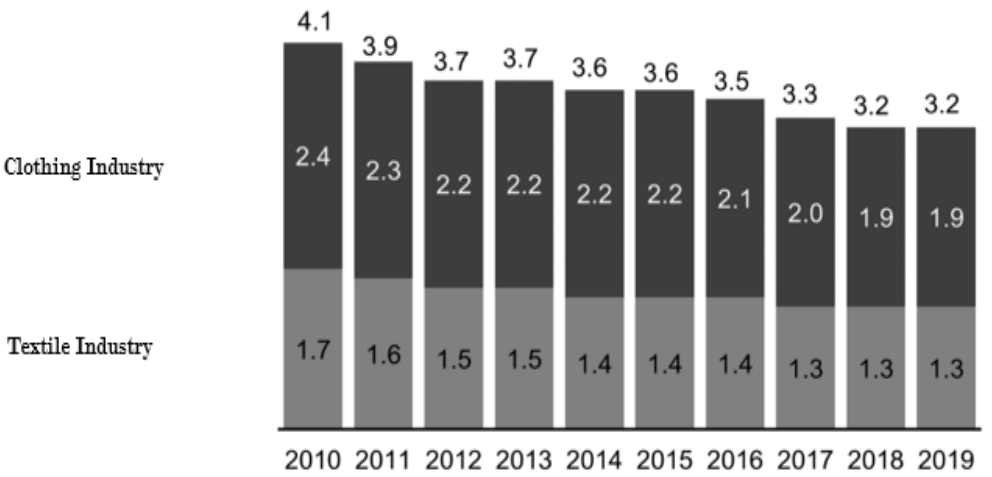

Figure 1. Participation of the textile and clothing industry in Mexico's GDP (INEGI, 2020b)

Through the analysis of Figure 1, we can see how the contribution of this industry has decreased from 2010 to date. In 2019, it represented 3.2\% of the national GDP, the lowest in ten years, and was ranked 10th among the most important manufacturing economic activities in 2019 (INEGI, 2020b).

Another indicator that denotes the current situation of the Mexican textile sector is exports, which went from 8,631 million dollars in 2000 (Jiménez, Arroyo \& Vázquez, 2018) to 6,797 million dollars in 2018 (INEGI, 
2020b). As mentioned, the sector had its glory days when NAFTA started, but this changed in 2000, when China entered the World Trade Organization (WTO). This was further complicated by the commercial opening with China in 2010 (Gutiérrez, Sandoval \& Varela, 2018).

However, despite the casualties reported from 2000 onward, since 2015, the GDP of the textile and clothing industry has increased in relation to the production numbers observed in previous years, this coincides with the entry into force of the Textile Decree ${ }^{1}$, which seeks to promote this economic activity and develop its productivity, competitiveness, achieving, according to the most recent data, the 10th position within the most productive activities in Mexico and employing more than 640,000 people in 2018, not counting jobs within "informality" (INEGI, 2020b).

According to Gutiérrez et al., (2018), the MSMEs of the textile industry in Mexico have problems to achieve consolidation in the market, each company has specific and different factors that determine their situation, some do have strategies and development plans, but no investment in technology; others do have investment in technology, but not strategies. This is also observed in Ortiz et al., (2018) who found that Mexico has a comparative disadvantage that is due to different causes since there is a lack of modernization, lack of investment in research and development and is constantly threatened by new emerging forces such as Asian competitors. In addition to the above, there is an internal problem associated with the low use of technology, which has resulted in little industrial development and business concentration in the clothing industry.

This research focuses on analyzing how E-MKT influences business success, evaluated through performance. This is because authors such as Lonnqvist (2004) define this concept as the ability to measure business results compared to the proposed objectives.

This research seeks to determine and compare the influence of E-MKT on business success in microenterprises in the textile sector of Aguascalientes in two generational groups according to the age of the people who run the companies: young people, 18 to 45 years old, and older adults, 65 or older, comparing the impact this strategy has on both groups. Thus, this study formulates three hypotheses presented in Table 1.

Table 1. Research hypothesis

\begin{tabular}{cl}
\hline No & \multicolumn{1}{c}{ Hypothesis } \\
\hline H1 & $\begin{array}{l}\text { The E-MKT has an influence on business success in youth-managed micro-enterprises in the textile sector } \\
\text { in Aguascalientes. }\end{array}$ \\
H2 & $\begin{array}{l}\text { The E-MKT has an influence on business success in micro-enterprises in the textile sector managed by } \\
\text { older adults in Aguascalientes. } \\
\text { The E-MKT has a greater influence on business success in micro-enterprises in the textile sector managed } \\
\text { by young adults than in those managed by elderly adults in Aguascalientes. }\end{array}$ \\
\hline
\end{tabular}

Source: Own development

\section{Method}

The instrument used for this research consists of three sections, using a set of 25 items. Section 1 included nine items regarding company's basic information. Section II, with four items, corresponds to the E-MKT, whilst section III refers to business performance and has nine items. All the scale items in parts II and III were measured using a five-point Likert-type category-scaling format $(1=$ Strongly Disagree, $2=$ Disagree, $3=$ Neutral, $4=$ Agree, and $5=$ Strongly Agree). Scale items were taken from previously validated scales, based on the authors presented in Table 2.

Table 2. Questionnaire structure

\begin{tabular}{lll}
\hline Part & Scale & Author \\
\hline I & Company's data & Does not apply \\
II & E-marketing & Yousaf, Sahar, Majid y Rafiq, (2017). \\
III & Business performance & Maldonado et al. (2013). \\
\hline
\end{tabular}

Source: Own Development

${ }^{1}$ This decree was published in the Official Gazette of the Federation (DOF) on December 26, 2014 "Decree establishing measures for productivity, competitiveness and combat of undervaluation practices in the textile and clothing sectors". 
This research was carried out with a quantitative approach on MSMEs of the textile sector in the city of Aguascalientes, Mexico. The sample was defined with data from National Statistical Directory of Economic Units (2018), known as DENUE. Companies were segmented by sector and company size, according to the number of employees and income to be named as a micro, small or medium-sized company. The total population based on this information was 635 organizations within these commercial activities.

The sample size was determined by means of the sample size formula for finite populations. Derived from this, a representative sample of 240 was obtained, with a confidence level of $95 \% .300$ surveys were carried out to MSMEs in the textile sector, chosen through simple random sampling, of which 292 were valid. Surveys were applied to owners or managers of the MSMEs of the textile sector of Aguascalientes, Mexico through a personal interview. Table number 3 presents the above information summarized.

Table 3. Research sample

\begin{tabular}{ll}
\hline Population Size & 635 \\
Sample size & 292 \\
Location & Aguascalientes \\
Segment & MSMEs in the textile sector \\
Data collecting method & Individual survey \\
Data collection & April 2019 to November 2019 \\
\hline
\end{tabular}

Source: own development based on DENUE (2018).

\section{Results}

\subsection{Data Analysis and Results}

Through the statistical analysis performed, the derived results yielded the mean for each of the items of the two constructs, which started from a questionnaire with a 5-point Likert-type scale, this is how all results greater than 2.5 are above average. Table 4 shows each of the means together with their standard deviation, which indicates how dispersed the results of the total companies analyzed are with respect to their mean.

Table 4. Mean obtained from the sample for each of the items, standard deviation, and mean average per construct

\begin{tabular}{|c|c|c|c|c|c|c|}
\hline \multirow[b]{2}{*}{ Item } & \multicolumn{3}{|c|}{ Young adults } & \multicolumn{3}{|c|}{ Elderly adults } \\
\hline & Mean & $\begin{array}{l}\text { Standard } \\
\text { Deviation }\end{array}$ & $\begin{array}{l}\text { Average } \\
\text { mean }\end{array}$ & Mean & $\begin{array}{l}\text { Standard } \\
\text { Deviation }\end{array}$ & $\begin{array}{l}\text { Average } \\
\text { mean }\end{array}$ \\
\hline EM1 & 3.79 & 1.172 & & 3.59 & 1.403 & \\
\hline EM2 & 3.75 & 1.081 & 3.69 & 3.37 & 1.401 & 3.45 \\
\hline EM3 & 3.70 & 1.192 & & 3.59 & 1.379 & \\
\hline EM4 & 3.52 & 1.210 & & 3.25 & 1.397 & \\
\hline RE1 & 4.40 & 0.692 & & 4.39 & 0.871 & \\
\hline RE2 & 4.22 & 0.831 & & 4.19 & 0.819 & \\
\hline RE3 & 4.31 & 0.828 & & 4.07 & 0.926 & \\
\hline RE4 & 4.34 & 0.861 & & 4.20 & 0.943 & \\
\hline RE5 & 4.22 & 0.985 & & 4.12 & 1.001 & \\
\hline RE6 & 4.25 & 0.810 & 4.15 & 4.12 & 1.052 & 4.07 \\
\hline RE7 & 4.22 & 0.742 & & 4.02 & 0.919 & \\
\hline RE8 & 4.04 & 0.834 & & 4.00 & 1.114 & \\
\hline RE9 & 4.15 & 0.775 & & 4.00 & 1.034 & \\
\hline RE10 & 4.22 & 0.773 & & 4.02 & 1.042 & \\
\hline RE11 & 3.75 & 1.123 & & 3.81 & 1.196 & \\
\hline RE12 & 3.77 & 1.117 & & 3.90 & 1.078 & \\
\hline
\end{tabular}

Source: Own development using EQS 6.1

Table No. 4 shows the behavior of the means of each item, it is noticeable that the means and the average corresponding to E-MKT do not exceed 4 points, which tells us that the use of E-MKT in both groups is low. While the values of business success are higher than those of E-MKT, obtaining averages higher than 4 in the two groups. However, the most outstanding thing in table No. 4 is that in the group of young adults higher means were obtained on average for both constructs compared to the results obtained in the group of older adults, which means that this group has a greater inclination to the constructs measured in the companies in the sample 
segment: microenterprises in the textile sector in the city of Aguascalientes.

This is research is based on the model proposed in Figure 2, in which the relationships of each of the constructs are shown, as well as their dimensions and items. This model allows us to respond to the hypotheses raised once the structural equations have been carried out.

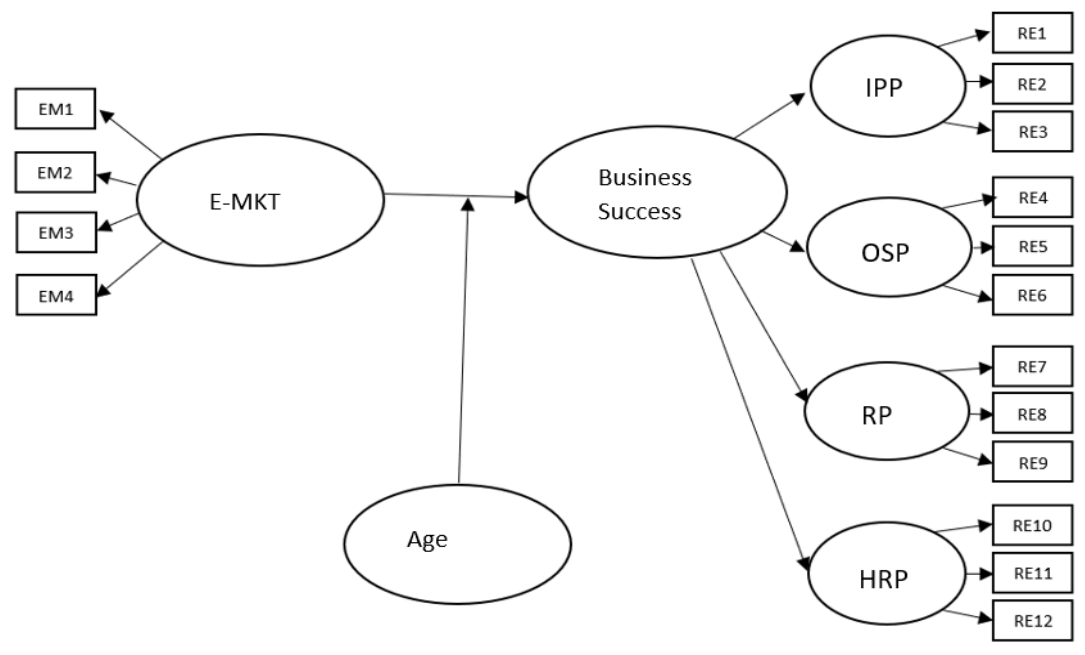

Figure 2. Research Model

Likewise, it is necessary to carry out a confirmatory factor analysis (CFA) for each construct in order to analyze the reliability and validity of the scales, using the maximum likelihood method with the EQS 6.1 software (Bentler, 2005; Brown, 2006; Byrne, 2006). The results of this analysis are show in table 5.

Table 5. Research model results analysis

\begin{tabular}{|c|c|c|c|c|c|c|}
\hline Construct & Item & Factor load & T- robust & Cronbach's $\alpha$ & C.R. & AVE \\
\hline \multirow[t]{4}{*}{ E-marketing } & EM1 & 0.774 & 1.000 & \multirow[t]{4}{*}{0.910} & \multirow[t]{4}{*}{0.911} & \multirow[t]{4}{*}{0.881} \\
\hline & EM2 & 0.887 & 10.306 & & & \\
\hline & EM3 & 0,899 & 9.844 & & & \\
\hline & EM4 & 0.831 & 8.064 & & & \\
\hline \multirow{3}{*}{$\begin{array}{l}\text { Internal } \\
\text { performance }\end{array}$} & RE1 & 0.742 & 1.000 & \multirow[t]{3}{*}{0.847} & \multirow[t]{3}{*}{0.857} & \\
\hline & RE2 & 0.841 & 6.900 & & & 0.801 \\
\hline & RE3 & 0.864 & 7.488 & & & \\
\hline \multirow[t]{3}{*}{ Open system performance } & RE4 & 0.791 & 1.000 & \multirow[t]{3}{*}{0.856} & \multirow[t]{3}{*}{0.858} & \multirow[t]{3}{*}{0.801} \\
\hline & RE5 & 0.842 & 8.733 & & & \\
\hline & RE6 & 0.819 & 6.343 & & & \\
\hline \multirow[t]{3}{*}{ Rational performance } & RE7 & 0.892 & 1.000 & \multirow[t]{3}{*}{0.899} & \multirow[t]{3}{*}{0.905} & \multirow[t]{3}{*}{0.879} \\
\hline & RE8 & 0.907 & 15.238 & & & \\
\hline & RE9 & 0.817 & 9.878 & & & \\
\hline Human & RE10 & 0.849 & 1.000 & \multirow[t]{3}{*}{0.848} & \multirow[t]{3}{*}{0.821} & \multirow[t]{3}{*}{0.736} \\
\hline \multirow{2}{*}{ performance } & RE11 & 0.760 & 10.740 & & & \\
\hline & RE12 & 0.721 & 10.261 & & & \\
\hline \multicolumn{7}{|c|}{ Note. $\mathrm{X}^{2} / \mathrm{df}=1.70 ; \mathrm{p}<0.000 ; \mathrm{NFI}=0.914 ; \mathrm{CFI}=0.929 ; \mathrm{RMSEA}=0.083$} \\
\hline
\end{tabular}

Source: Own development using EQS 6.1

The results obtained were evaluated by means of the Cronbach's alpha coefficient and the Composite Reliability index (CR) and the Average Variance Extracted (AVE) proposed by Bagozzi and Yi (1988), where values higher than $0.7,0.7$ and 0.5 , respectively. For the analysis of validity, it was performed through convergent validity where all items were significant, with factor loadings greater than 0.6 (Bagozzi \& Yi, 1988) and the average variance extracted (AVE) of each dimension of the constructs greater than 0.5 (Fornell \& Larcker, 1981).

\subsection{Hypothesis Test}

The results achieved through the structural equations modeling (SEM) were relevant, since the influence of the E-MKT on business success (performance) was positive and significant in both cases, which allows us to 
highlight that this construct influences business success, measured through performance. Although an influence of this construct on performance was found, it was not the same for both studied groups, young adults, and elderly adults. Finding a higher beta in the influence on performance in companies managed by young adults (0.501), compared to the group of companies managed by elders (0.334), highlighting that in both cases constructs are significant. The above information is summarized in table 6.

Table 6. Results of the hypotheses of the research model

\begin{tabular}{llll}
\hline Hypotheses & Structural relation & $\begin{array}{l}\text { Standardized } \\
\text { coefficient }\end{array}$ & T Robust \\
\hline $\begin{array}{l}\text { E-marketing has an influence on business success in } \\
\text { micro-enterprises in the textile sector in Aguascalientes } \\
\text { managed by young adults. }\end{array}$ & $\begin{array}{l}\text { E-marketing } \\
\text { Performance }\end{array}$ & $0.501 * * *$ & 2.208 \\
\hline $\begin{array}{l}\text { E-marketing has an influence on business success in } \\
\text { micro-enterprises in the textile sector in Aguascalientes } \\
\text { managed by elderly adults. }\end{array}$ & $\begin{array}{l}\text { E-marketing } \\
\text { Performance }\end{array}$ & $\rightarrow 0.334 * * *$ & 2.391 \\
\hline
\end{tabular}

Source: Own development using EQS 6.1

\section{Conclusions}

The results of this research were relevant, since they demonstrated that the E-MKT help companies achieve business success, being the case of the micro-companies of the textile sector of Aguascalientes. A segment to which the recurring crises, the opening of the economy and, therefore, of external competition from foreign textile and clothing products, brought to light its weakness of the competitive and creative structure (Vivanco, García \& Lozano, 2015).

By carrying out this research in a quantitative way, the current situation of this segment is demonstrated through the means obtained for each of the items. The items of the E-MKT construct had means lower than four, which shows that these companies do not carry out high rates of activities related to this variable, not necessarily an advanced use of these tools, but simply their implementation to some extent. Having an average mean below 4 is a fact that should be worrying, since, although E-MKT is a powerful and low-cost tool (El-Gohary, 2012), it is not being used sufficiently.

The means obtained for the business success construct were higher than those of E-MKT for both groups and very close to 5 , which is a subjective form of self-evaluation of their companies, giving the possibility that it is not the real situation of these companies since the textile sector worldwide is characterized by low growth and success rates (Vila \& Kuster, 2015). Completely contrasted with the E-MKT construct that presents lower averages, an essential tool for doing business in recent years (Awiagah, Kang \& Lim, 2016).

The textile sector in Aguascalientes and in the world, houses companies with similar characteristics, however, the age of the managers or directors endows companies with specific characteristics that are reflected in the strategies and actions they take. That is why this research is important, since technology is a core issue in companies, and the age of directors and managers influences the inclination to new ways of doing business and using marketing strategies and tools.

The results of this research show that companies managed by young adults have better levels of E-MKT than those managed by elderly adults and therefore obtain better results evidenced by business success. Consequently, the verification of the hypotheses raised was achieved, demonstrating that the E-MKT is a key strategy for companies and that it has a positive and significant influence on business success regardless of the age of the manager or director of the companies.

On the other hand, in addition to accepting the first two hypotheses, this research succeeded in showing that companies managed by young people obtain better means for both constructs, as well as higher results on business success when using E-MKT as a strategy. That is why the third hypothesis is accepted, because the E-MKT has a greater influence on business success in micro-enterprises in the textile sector managed by young adults than in those managed by elderly adults in Aguascalientes.

\section{References}

Abu Bakar, A. R., \& Ahmed, Z. U. (2015). Technology motivation in e-marketing adoption among Malaysian manufacturers. Journal of Transnational Management, 20(2), 126-152.

https://doi.org/10.1080/15475778.2015.1038949 
Anser, M. K., Yousaf, Z., Usman, M., \& Yousaf, S. (2020). Towards Strategic Business Performance of the Hospitality Sector: Nexus of ICT, E-marketing and Organizational Readiness. Sustainability, 12(4), 1346. https://doi.org/10.3390/su12041346

Awiagah, R., Kang, J., \& Lim, J. (2016). Factors affecting e-commerce adoption among SMEs in Ghana. Information Development, 815-836. https://doi.org/10.1177/0266666915571427

Bagozzi, R., \& Yi, Y. (1988). On the evaluation of structural equation models. Journal of the Academy of Marketing Science, 74-94. https://doi.org/10.1007/BF02723327

Bala, M., \& Verma, D. (2018). A Critical Review of Digital Marketing. International Journal of Management, IT \& Engineering, 8(10), 321-339.

Barney, J. (1991). Firm resources and sustained competitive advantage. Journal of management, 17(1), 99-120. https://doi.org/10.1177/014920639101700108

Bentler, P. (2005). EQS 6 Structural Equations Program Manual. Multivariate Software. Encino, California, USA.

Brown, T. (2006). Confirmatory Factor Analysis for Applied Research. New York USA: The Guilford Press.

Bruce, N. I., Foutz, N. Z., \& Kolsarici, C. (2012). Dynamic effectiveness of advertising and word of mouth in sequential distribution of new products. Journal of Marketing Research, 49(4), 469-486. https://doi.org/10.1509/jmr.07.0441

Byrne, B. (2006). Structural Equation Modeling With EQS, Basic Concepts, Applications, and Programming. New York, USA: LEA Publishers.

Colicev, A., Malshe, A., Pauwels, K., \& O'Connor, P. (2018). Improving consumer mindset metrics and shareholder value through social media: The different roles of owned and earned media. Journal of Marketing, 82(1), 37-56. https://doi.org/10.1509/jm.16.0055

DENUE. (2018). Directorio Estadístico Nacional de Unidades Económicas 2018. Retrieved from http://www3.inegi.org.mx/rnm/ index.php/ catalog/341

Dinner, I. M., Heerde Van, H. J., \& Neslin, S. A. (2014). Driving online and offline sales: The cross-channel effects of traditional, online display, and paid search advertising. Journal of marketing research, 51(5), 527-545. https://doi.org/10.1509/jmr.11.0466

El-Gohary, H. (2012). Factors affecting E-Marketing adoption and implementation in tourism firms: An empirical investigation of Egyptian small tourism organisations. Tourism management, 33(5), 1256-1269. https://doi.org/10.1016/j.tourman.2011.10.013

Fong Reynoso, C., Flores Valenzuela, K. E., \& Cardoza Campos, L. M. (2017). La teoría de recursos y capacidades: un análisis bibliométrico. Nova scientia, 9(19), 411-440. https://doi.org/10.21640/ns.v9i19.739

Fornell, C., \& Larcker, D. (1981). Evaluating structural equation models with unobservable variables and measurement error. Journal of Marketing Research, 39-50. https://doi.org/10.1177/002224378101800104

García, J. L., Lozano, F. P., \& Castorena, P. G. (2018). Capítulo 1 Impacto de la globalización en la industria textil de Aguascalientes: Cambios y transformaciones. En Sistemas financieros y fiscales y su impacto en las organizaciones (pp. 3-16). Casia Creaciones.

Ghermandi, F. (21 de febrero de 2018). Blog Luz. Recuperado el 21 de octubre de 2020, de Evaluación de rendimiento y gestión de rendimiento: cuál es la diferencia? Retrived from https://blog.luz.vc/es/que-es/Evaluaci\%C3\%B3n-de-rendimiento-y-de-gesti\%C3\%B3n-basada-en-el-desem pe $\%$ C $3 \% \mathrm{~B} 1 \mathrm{o} /$

Grand view research. (2020). Textile Market Size, Share \& Trends Analysis Report. San Francisco: Grand view research.

Gutiérrez, J. S., Sandoval, M. V., \& Varela, L. M. R. (2018). Estrategias competitivas en la industria textil en Jalisco, ante la liberación comercial con China. Red Internacional de Investigadores en Competitividad, $6(1)$.

INEGI. (March 2020b). www.inegi.org.mx. Retrieved from https://www.inegi.org.mx/contenido/productos/prod_serv/contenidos/espanol/bvinegi/productos/nueva_estr uc/702825195649.pdf

INEGI. (May 2020a). www.inegi.org.mx. Retrieved from 
https://www.inegi.org.mx/contenidos/saladeprensa/boletines/2020/OtrTemEcon/Indtiatextil2020.pdf

Jiménez, M. A. V., Arroyo, J. A. M., \& Vázquez, G. C. (2018). El estudio del Balanced Scorecard desde la Perspectiva del Cliente en la Industria Textil en Guanajuato, México. Red Internacional de Investigadores en Competitividad, 11, 1451-1467.

Khan, A. R., \& Islam, A. (2017). The Impact of Digital Marketing on Increasing Customer Loyalty: A study on Dhaka City, Bangladesh. International Journal of Economics, Commerce and Management, 5(4), 521-528.

Kotler, P., \& Armstrong, G. (2009). Principles of Marketing, Learned Nshrasly, Tehran.

Li, H., \& Kannan, P. K. (2014). Attributing conversions in a multichannel online marketing environment: An empirical model and a field experiment. Journal of Marketing Research,51(1), 40-56. https://doi.org/10.1509/jmr.13.0050

Liu, S., Perry, P., \& Gadzinski, G. (2019). The implications of digital marketing on WeChat for luxury fashion brands in China. Journal of Brand Management, 26(4), 395-409. https://doi.org/10.1057/s41262-018-0140-2

Lonnqvist, A. (2004). Measurement of intangible success factors: Case studies on the desing, implementation and use of measures. Tampere: Tampere university of technology.

Maldonado, G., Garza, J. A., Pinzón, S. Y., \& Kumar, V. (2017). Barriers to innovation in service SMEs: evidence from Mexico. Industrial Management \& Data Systems, 1669-1686. https://doi.org/10.1108/IMDS-08-2016-0339

Maldonado, G., Martínez, M. C., García, D., Aguilera, L., González, M., \& Vivanco, S. (2013). Capacidad de internacionalización, actividad innovadora e intraemprendimiento en la MiPyME: un análisis cross cultural Aguascalientes-Murcia. Aguascalientes: Universidad Autónoma de Aguascalientes.

Mzee, R. M., Ogweno, K. L., \& Irene, N. (2015). Factors influencing Adoption of E marketing by small and Medium Enterprises (SMEs) in Kisumu Municipality. Journal of Business and Management, 17(5), 78-83.

Ollo-López, A., \& Aramendía-Muneta, M. E. (2012). ICT impact on competitiveness, innovation and environment. Telematics and Informatics, 29(2), 204-210. https://doi.org/10.1016/j.tele.2011.08.002

Ortiz, A. L., Gómez, M., y Rodríguez, J. C. (2018). Competitividad de la industria textil y de la confección en México 1990-2015. Revista Nicolaita de Estudios Económicos, 13(2). https://doi.org/10.33110/rnee.v13i2.268

Pandey, N., \& Gudipudi, B. (2019). Understanding 'what is privacy' for millennials on Facebook in India. Journal of Data Protection \& Privacy, 2(3), 224-233.

Pandey, N., Nayal, P., \& Rathore, A. S. (2020). Digital marketing for B2B organizations: structured literature review and future research directions. Journal of Business \& Industrial Marketing, 35(7), 1191-1204. https://doi.org/10.1108/JBIM-06-2019-0283

Porter, M. E. (1980). Competitive Strategy, New York Free Press. Porter Competitive Strategy 1980.

Selman, Y. H. (2017). Marketing digital. Ibukku.

Sosa Tota, A. S., \& Useche Aguirre, M. C. (2017). Marketing digital en universidades privadas en el estado Zulia. Poliantea, 13(24), 5-26. https://doi.org/10.15765/plnt.v13i24.1001

Stankov, U., Filimonau, V., \& Slivar, I. (2019). Calm ICT design in hotels: A critical review of applications and implications. International Journal of Hospitality Management, 82, 298-307. https://doi.org/10.1016/j.ijhm.2018.10.012

Stephen, A. T., \& Galak, J. (2012). The effects of traditional and social earned media on sales: A study of a microlending marketplace. Journal of marketing research, 49(5), 624-639. https://doi.org/10.1509/jmr.09.0401

Teece, D. J., Pisano, G., \& Shuen, A. (1997). Dynamic capabilities and strategic management. Strategic management journal, 18(7), 509-533. https://doi.org/10.1002/(SICI)1097-0266(199708)18:7<509::AID-SMJ882>3.0.CO;2-Z

The CMO Survey. (Febrero 2020). Highlights and insights report. Retrieved from https://cmosurvey.org/wp-content/uploads/2020/02/The_CMO_Survey-Highlights-and_Insights_Report-Fe b-2020.pdf 
Usman, M., Ahmad, M. I., \& Burgoyne, J. (2019). Individual and organizational learning from inter - firm knowledge sharing: A framework integrating inter - firm and intra - firm knowledge sharing and learning. Canadian Journal of Administrative Sciences/Revue Canadienne des Sciences de l'Administration, 36(4), 484-497. https://doi.org/10.1002/cjas.1517

Valdez, L., Ramos, E., \& Borboa, E. (2019). The Dynamic Capabilities and the Entrepreneurial Orientation: Source of Innovation and Profitability in the Mexican SME. Small Business International Review, 3(1), 49-66. https://doi.org/10.26784/sbir.v3i1.158

Venkatesh, R., Mathew, L., \& Singhal, T. K. (2019). Imperatives of business models and digital transformation for digital services providers. International Journal of Business Data Communications and Networking, 15(1), 105-124. https://doi.org/10.4018/IJBDCN.2019010107

Vieira, V. A., de Almeida, M. I. S., Agnihotri, R., \& Arunachalam, S. (2019). In pursuit of an effective B2B digital marketing strategy in an emerging market. Journal of the Academy of Marketing Science, 47(6), 1085-1108. https://doi.org/10.1007/s11747-019-00687-1

Vila, N., \& Küster, I. (2015). Conduce la internacionalización al éxito de una empresa familiar? aplicación al sector textil. Innovar, 43-52. https://doi.org/10.15446/innovar.v25n56.48988

Villagómez, P. Z., Montoya, D. A., \& Figueroa, E. G. (2019). El Perfil del Empresario Y Las Empresas De La Industria de la confección del vestido (MIPYMES) De Moroleón, Guanajuato, México. Revista de la Facultad de Contaduría y Ciencias Administrativas, 4(7), 41-53.

Vivanco J. S., García, J. L., \& Lozano, F. P. (2015). La apertura comercial y las Mipymes del sector textil y del vestido en Aguascalientes. En Flores, R., Vidrio, S., Arechiga, B. y Flores, R. (Ed.), Innovaciones y puntos clave para el desarrollo de las organizaciones competitividad, calidad, educación, conocimiento, responsabilidad social, finanzas (pp. 3-14). Competitive Press.

Vivanco, J. S., \& Franco, R. E. (Octubre 2012). Los tipos de cultura organizacional yelrendimiento de las pymes en Aguascalientes. Trabajo presentado en la Facultad de contaduría y administración en el XVII Congreso Internacional de contaduría adminitración e informática. Ciudad de México.

Wernerfelt, B. (1984). A resource - based view of the firm. Strategic management journal, 5(2), 171-180. https://doi.org/10.1002/smj.4250050207

\section{Copyrights}

Copyright for this article is retained by the author(s), with first publication rights granted to the journal.

This is an open-access article distributed under the terms and conditions of the Creative Commons Attribution license (http://creativecommons.org/licenses/by/4.0/). 